\title{
Language Perceptions and Communication in the Baghdad Turkmen Community
}

\author{
Prof. Bader S. Dweik (Corresponding author) \\ Dept. of English, Middle East University \\ Airport Road, P.O. Box: 383 Amman, 11831, Jordan \\ E-mail:drdweik@yahoo.com \\ Sara N. Al-Rahal \\ Dept. of English, Middle East University \\ Jordan \\ E-mail: sara_84na@@yahoo.com
}

Received: January 31, 2016 Accepted: April 22, 2016 Published: December 23, 2016

doi:10.5296/ijch.v3i2.8960ＵRL: http://dx.doi.org/10.5296/ijch.v3i2.8960

\begin{abstract}
The purpose of this study is to investigate the domains of use of the Turkmen language and Arabic in Baghdad and to explore attitudes towards Turkmen and Arabic. A sample, comprising (100) subjects from the Turkmen of Baghdad, is selected purposefully to fill out a sociolinguistic questionnaire to solicit information about the participants' demographic background, language use in different contexts and language attitudes towards the ethnic language, Turkmen and the mainstream language, Arabic. The results have revealed that the Turkmen of Baghdad use their ethnic language in different domains especially at home and among the family members. Also, they use both languages (their ethnic language and Arabic) in different social domains such as neighborhood, place of work, schools, media and other public places and have displayed positive attitudes towards Turkmen and Arabic alike.
\end{abstract}

Keywords: Language use, Language perceptions, Communication, Turkmen, Baghdad

\section{Introduction}

There are many minorities in the world who have lived with majorities side by side in one 
country for many centuries. Each group has its own language, some of them maintain their language and consider it as their identity while others shift to the language of the majority. In both cases, there are either linguistic or non-linguistic factors that stand behind the maintenance or the loss of their languages.

The Turkmen, who are the focal point of this research, are the Oghuz who migrated from Central Asia to Iraq . They were named Turkmen after choosing Islam. The Turkmen migrated because of many various political situations at different times and chose Iraq as their motherland. Somer (1967) states that "the word Turkmen was given to those of the Turkish Oguz tribes who embraced Islam in the 11th Century." (p. 10).

The presence of more than one language in the same country may have an impact on the linguistic situation of each language, especially when there is one official language, regardless of the languages of other minorities. Baghdad is characterized by the presence of more than one minority and every one of them has its own language such as the Kurds, the Turkmen, the Shabak, and the Yazidis.

The aim of the study at hand is to examine the languages which are being used by the Turkmen of Baghdad in different domains, with different people and when discussing different topics. It also aims to explore their attitudes towards the ethnic Turkmen language and Arabic as a language of the majority.

To achieve these objectives, the study intends to answer the following questions:

1. In what domains do the Turkmen of Baghdad use their ethnic language and Arabic?

2. What are their attitudes towards both languages (the Turkmen language and Arabic)?

Many studies have dealt with ethnic minorities in the Middle East, but to the best of the researchers' knowledge, studies that have investigated language use and attitudes among the Turkmen of Iraq are few. Although some researchers have shed light on the Turkmen of Iraq, this study is distinguishes from others its focus on bilingualism, especially language use and attitudes of a minority that existed in Iraq for a long period of time. Studies conducted in Jordan for example dealt with small ethnic minorities, i.e. the Chechens, the Circassians, the Armenians, the Kurds and the Gypsies etc. The Turkmen of Iraq are considered a large ethnic minority that did not receive the attention of researchers and scholars.

This study is expected to help other researchers, scholars, educators, students as well as members of the selected community. Results of this study are limited to the sample and instruments used in this research. Therefore, the findings of the study cannot be generalized to all the Turkmen of Baghdad.

\section{Review of Literature}

Theoretically, many scholars like Fishman (1989), Clyne (2001) and Holmes (1992)discussed the issues of language use and attitudes. Fishman (1989) commented on the three possible resolutions when languages are in contact. Fishman maintained that some immigrant languages could dominate and become more powerful than the host language as the case of 
English in the USA. The second resolution is when the host language dominates as the case of Arabic in some countries like Jordan. The third resolution is when the two languages are used side by side. Each language is used in certain domains and has positive attitudes by its speakers.

Likewise, Clyne (2001) discussed the significance of the home and family in language preservation, especially grandparents. She pointed out that "grandparents rather than parents play an increasing role in the intergenerational language maintenance.” (p.367).

Regarding attitudes, Holmes (1992) discussed three levels of attitudes towards ethnic groups. The first level is that of attitudes towards the ethnic group as a whole. The second is that of attitudes towards the language of that group and the third is attitude towards individual speakers of that language. People generally do not hold opinions about languages in a vacuum. They develop attitudes towards language which reflect their views about those who speak the language, and the contents and functions with which they are associated. Holmes pointed out that the underlying assumption is that in a society, social or ethnic groups have certain attitudes towards each other, relating to their differing positions. These attitudes affect "attitudes towards cultural institutions or patterns characterizing these groups such as language, and carry over to and are reflected in attitudes towards individual members of the group". (P.16)

Empirically, Park and Sarkar (2007) investigated Korean immigrant parents' attitudes towards heritage language maintenance for their children and their efforts to help their children maintain Korean as their heritage language in Montreal. Data were collected from nine Korean immigrant parents who had a child (or children) between the ages of 6-18 in (2005) by using a questionnaire and interviews. The findings suggested that Korean immigrant parents were very positive towards their children's heritage language maintenance. Korean parents believed that their children's high level of proficiency in the Korean language would help their children keep their cultural identity as Koreans, ensure them better future economic opportunities, and give them more chances to communicate with their grandparents efficiently.

Zhang \& Slaughter-Defoe (2009) explored attitudes towards heritage language maintenance among Chinese immigrant parents and their second-generation children. Data were collected through participant observations in two Chinese local communities in Philadelphia and ethnographic interviews with 18 Chinese immigrant families in the communities. Analysis of the data indicated that while the Chinese parents value their heritage language as a resource and take positive actions to maintain the heritage language in the next generation, the children fail to see the relevance of heritage language learning in their life and often resist parents' efforts in heritage language maintenance. The results of the study suggested that American mainstream schools should work together with immigrant parents and heritage language schools to incorporate children's heritage language in the official school curriculum and create a supportive environment for heritage language learning.

Jagodic (2011) examined the language use patterns among the Slovenian population in Italy. The quantitative study took into consideration 200 subjects. The interviewees belonged to 
two different age generations: the first consisted of 100 subjects between 35 and 36 years old, while the second generation included 100 subjects between 16 and 20 years old. The data were obtained through a series of interviews based on a structured questionnaire. The aim of the interviews was to collect information on the use of the minority language (Slovenian) and the majority language (Italian) according to a series of social domains. The results emphasize how the use of the minority language is still dominant in the more intimate and informal situations.

In Algeria, Khadidja (2013) investigated the different attitudes of the Kabyle minority group living in Oran towards the four languages that include their speech repertoire i.e Algerian Arabic, Standard Arabic, French and Kabyle. Also this study aimed to analyse their attitudes towards code switching, the contact phenomenon that characterizes the sociolinguistic situation of this bilingual environment. The sample of this study included 100 respondents from the Kabyle minority group living in Oran .Data were collected through recording Kabyle interlocutors' conversations and a questionnaire. The findings pointed that the Kabyle speakers of Oran manifest positive attitudes towards their native language. These positive attitudes may play a significant role in the maintenance of the Kabyle variety in the speech community of Oran where the predominant language is Algerian Arabic. Also, the results showed that the members of this minority speech group express their belonging and loyalty to the Kabyle language and culture through the use of their minority language in different contexts.

In Iraq, Dweik and Al-Obaidi (2014) explored language use and language attitudes among the Chaldo-Assyrians of Baghdad. They selected a sample that consisted of (135) participants. Interviews and a sociolinguistic questionnaire were the instruments of the study. Results indicated that the Chaldo-Assyrians of Baghdad used Syriac in various domains mainly in the home home, in religious settings and in their inner speech; and used it side by side with Arabic in many other social domains such as neighborhood, place of work, media and other public places. The study showed that the participants' attitudes towards Syriac and Arabic were highly positive.

In Canada, Dweik and Qawar (2015) investigated language choice among Arabs of QuebecCanada. It also explored Arabs' attitudes towards Arabic, French and English in particular and factors involved in using these languages. In order to achieve the objectives of the study, the researchers selected a sample that consisted of (100) Arab respondents who reside in Quebec- Canada, covering different age ranges, gender, and educational backgrounds. The instrument of the study was a sociolinguistic questionnaire.Results showed that Arabs of Quebec-Canada have positive attitudes towards Arabic, English and French. They freely use their Arabic language in the domain of home and with family members, in worship places and when listening to the radio. In addition, they use English and French in Governmental offices and formal applications and in educational institutions. Results also showed that Arabs of Quebec mix these languages in the domain of neighborhood, with friends, and media.

In Yemen, Dweik and Nofal (2015) studied language choice and attitudes among the Indians of Yemen. Two research questions concerning domains of language use and attitudes towards 
each language guided the study. The eighty-six-participant sample was selected on grounds of convenience where they responded to a language questionnaire. Results showed the Indians of Yemen used the Indian ethnic languages in several situations most significantly at home. They illustrated habitual use of the Indian ethnic languages with several members of the family. Moreover, they used the Indian ethnic languages in the neighbourhood, in the media and in emotional self-expressions. Additionally, Results showed that the Indians of Yemen possessed positive attitudes towards the Indian ethnic languages and towards Arabic.

\section{Methodology}

The population consisted of the Turkmen of Baghdad in general. A sample of 100 selected purposefully from different areas in Baghdad. The demographic background information about the participants' general background included data such as gender, age, religion, marital status, residency, level of education and the language of mother and father.

To achieve the objectives of the study, the researchers used a sociolinguistic questionnaire. The researchers designed a questionnaire which was developed specifically to meet the needs of this study. The questionnaires relied on similar previous questionnaires designed by other researchers who investigated many ethnic minorities in different places in the world such as Khadidja (2013), Dweik \& Al-Obaidy (2014) and Dweik and Nofal (2015). They adapted and modified them to suit the community under investigation. The questionnaire was validated and tested before it was administered to a sample of Turkmen in Baghdad.

The questionnaire consisted of three sections. The first section of the questionnaire included demographic background information about the participants such as gender, age, marital status, level of education, the language of the parents, level of language proficiency in both languages and the occupations of the participants.

The second section sought to uncover the languages used within the Turkmen's community and also with people outside the community. This section was designed to discover the choice of languages at different domains of use of the Turkmen language and Arabic. It contained ten domains of language use in different places with different people starting from home, neighborhood, school and university, work, meeting new people, government officials, shopping and going to local business, places of worship (Mosque), media and finally emotional self-expressions.

The participants were asked to choose the suitable answer from the following options:

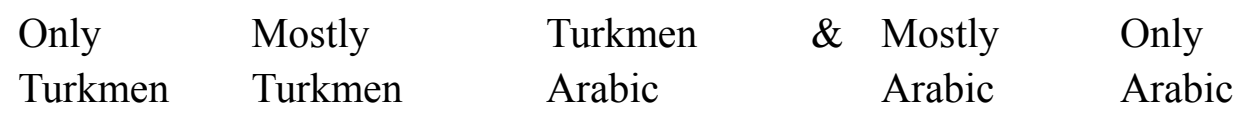

The family and home domain included nine items which dealt with different family members and occasions, such as father, mother, children, brothers, sisters, grandparents, family and relative meetings, calling etc... Two items covered language use in the neighborhood with friends in the neighborhood and with all neighbors in general .It also covered language use at school/university with boss and teachers and with friends. 
According to language use at work, three items were asked with fellow employees, boss discussing business and general topics with colleagues at work (weather, sports, politics... etc.). Three items dealt with the language used in meeting new people, with government officials and shopping in local businesses. Two additional items focused on language use in places of worship (Mosque) such as in prayer and when speaking with fellow worshippers.

Furthermore, three items were concerned with the language use in media such as TV entertainment, radio programs and the language used in reading newspapers. Finally, four items covered language use in inner speech such as, expressing emotions like happiness, anger, confusion and in dreaming.

The third section elicited the participants' attitudes and feelings towards the ethnic language of the Turkmen and Arabic. The researchers used both open-ended and controlled questions in which the participants were asked to read statements and indicate to what degree they agree with them. Each statement was given five options:

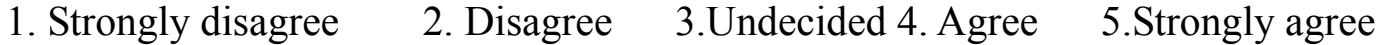

It consisted of twenty-three statements, fourteen statements intended to solicit the participant's attitudes and feelings towards Turkmen language while other statements focused on their attitudes and feelings towards Arabic.

\section{Results}

The first question deals with the language that the Turkmen use in different domains including home, neighborhood, school/university, workplace, meeting new people, government officials, shopping, place of worship ,media and emotional self - expressions with different people. The participants were asked to choose the suitable answer from a five-point scale that consists of Only Turkmen; Mostly Turkmen; Both Turkmen and Arabic; Mostly Arabic; and Only Arabic.

Table 1 shows the results of the languages that the participants use at home and when they talk with family members. The results indicate that the majority of the participants use the Turkmen language with their family members and relatives and $96 \%$ of them use it with their fathers while $4 \%$ of them use both Turkmen and Arabic. Similarly, 98\% of them use the Turkmen language with their mothers and only $2 \%$ use both Turkmen and Arabic. It is reported that $70 \%$ of the participants, who are married, use the Turkmen language with their children and only $10 \%$ use both languages with children. The remaining $20 \%$ reported that they are single. Similarly, 94\% use the Turkmen language with their brothers / sisters and 6\% use both Turkmen and Arabic. Finally, 98\% use the Turkmen language with their grandfathers and grandmothers while $2 \%$ use both Turkmen and Arabic. The results also show that $94 \%$ of the participants use the Turkmen language during phone calls with family members and only $6 \%$ use both languages . Similarly, $90 \%$ use the Turkmen language at family meetings while $10 \%$ use both languages in addition to $94 \%$ use it when meeting them face-to-face while $6 \%$ use both languages. 
Table 1. Language use at home and among the family members

\begin{tabular}{|c|c|c|c|c|c|c|}
\hline Questions & $\begin{array}{c}\text { Only } \\
\text { Turkmen } \\
\% \\
\end{array}$ & $\begin{array}{c}\text { Mostly } \\
\text { Turkmen } \\
\%\end{array}$ & $\begin{array}{c}\text { Turkmen } \\
\& \text { Arabic } \\
\%\end{array}$ & $\begin{array}{c}\text { Mostly } \\
\text { Arabic } \\
\%\end{array}$ & $\begin{array}{c}\text { Only } \\
\text { Arabic } \\
\%\end{array}$ & $\begin{array}{c}\text { Total } \\
\%\end{array}$ \\
\hline \multicolumn{7}{|l|}{$\begin{array}{l}\text { 1. What language do you speak } \\
\text { with family members }\end{array}$} \\
\hline your father? & 90 & 6 & 4 & - & - & 100 \\
\hline your mother? & 92 & 6 & 2 & - & - & 100 \\
\hline your children? & 66 & 4 & 10 & - & - & 80 \\
\hline your brothers / sisters? & 90 & 4 & 6 & - & - & 100 \\
\hline your grandfather? & 98 & 2 & - & - & - & 100 \\
\hline your grandmother? & 98 & 2 & - & - & - & 100 \\
\hline $\begin{array}{l}\text { family members during phone } \\
\text { call? }\end{array}$ & 88 & 6 & 6 & - & - & 100 \\
\hline at family meetings? & 84 & 6 & 10 & - & - & 100 \\
\hline $\begin{array}{l}\text { your relatives when you meet } \\
\text { them face to face? }\end{array}$ & 90 & 4 & 6 & - & - & 100 \\
\hline
\end{tabular}

Concerning the language used in the neighborhood, Table 2 below shows that $72 \%$ of the participants use Arabic with their friends in the neighborhood. Also, the results show that $22 \%$ of them use both languages and only $6 \%$ use the Turkmen language. The results also show that $78 \%$ of them use Arabic with their neighbors while $20 \%$ use both languages and $2 \%$ use the Turkmen language.

Table 2. Language use in the neighborhood

\begin{tabular}{|l|c|c|c|c|c|c|}
\hline \multicolumn{1}{|c|}{ Questions } & $\begin{array}{c}\text { Only } \\
\text { Turkmen } \\
\%\end{array}$ & $\begin{array}{c}\text { Mostly } \\
\text { Turkmen } \\
\%\end{array}$ & $\begin{array}{c}\text { Turkmen } \\
\& \text { Arabic } \\
\%\end{array}$ & $\begin{array}{c}\text { Mostly } \\
\text { Arabic } \\
\%\end{array}$ & $\begin{array}{c}\text { Only } \\
\text { Arabic } \\
\%\end{array}$ & Total \% \\
\hline $\begin{array}{l}\text { 2. What language do } \\
\text { you use in the } \\
\text { Neighborhood with }\end{array}$ & 2 & 4 & 22 & 40 & 32 & 100 \\
\hline $\begin{array}{l}\text { your friends in the } \\
\text { neighborhood? }\end{array}$ & 2 & - & 20 & 36 & 42 & 100 \\
\hline your neighbors? & & & & & & \\
\hline
\end{tabular}

Regarding the language used at the school and university, Table 3 below shows that $80 \%$ of the participants use Arabic when they talk with their teachers, $12 \%$ use both languages whereas $8 \%$ use the Turkmen language. Similarly, $76 \%$ of the participants use Arabic when they talk with their friends; only $18 \%$ use both languages and just $6 \%$ use the Turkmen language. 
Table 3. Language use at schools and universities

\begin{tabular}{|l|c|c|c|c|c|c|}
\hline \multicolumn{1}{|c|}{ Questions } & $\begin{array}{c}\text { Only } \\
\text { Turkmen } \\
\%\end{array}$ & $\begin{array}{c}\text { Mostly } \\
\text { Turkmen } \\
\%\end{array}$ & $\begin{array}{c}\text { Turkmen } \\
\& \text { Arabic } \\
\%\end{array}$ & $\begin{array}{c}\text { Mostly } \\
\text { Arabic } \\
\%\end{array}$ & $\begin{array}{c}\text { Only } \\
\text { Arabic } \\
\%\end{array}$ & Total \% \\
\hline $\begin{array}{l}\text { 3.What language do you } \\
\text { use at school/university } \\
\text { with }\end{array}$ & & & & & & \\
\hline your teachers? & 4 & 4 & 12 & 26 & 54 & 100 \\
\hline your friends? & 2 & 4 & 18 & 28 & 48 & 100 \\
\hline
\end{tabular}

Table 4 below shows the language used at work with fellow employees. It is reported that $78 \%$ of the participants use Arabic when they talk with fellow employees and only $10 \%$ use both languages and another $12 \%$ use the Turkmen language. Moreover, $88 \%$ of the participants use Arabic when they discuss business and technical matters with the boss while $8 \%$ use both languages and only $4 \%$ use only the Turkmen language. When discussing general topics with their colleagues at work such as weather, sports, politics... etc., the results show that $76 \%$ of the participants prefer to use Arabic, $16 \%$ use both languages and only $8 \%$ of them use the Turkmen language.

Table 4. Language use at work

\begin{tabular}{|l|c|c|c|c|c|c|}
\hline \multicolumn{1}{|c|}{ Questions } & $\begin{array}{c}\text { Only } \\
\text { Turkmen } \\
\%\end{array}$ & $\begin{array}{c}\text { Mostly } \\
\text { Turkmen } \\
\%\end{array}$ & $\begin{array}{c}\text { Turkmen } \\
\& \\
\text { Arabic } \\
\%\end{array}$ & $\begin{array}{c}\text { Mostly } \\
\text { Arabic } \\
\%\end{array}$ & $\begin{array}{c}\text { Only } \\
\text { Arabic } \\
\%\end{array}$ & Total \% \\
\hline $\begin{array}{l}\text { 4. What language do you use at } \\
\text { work with }\end{array}$ & 6 & 6 & 10 & 32 & 46 & 100 \\
\hline your fellow employees? & 4 & - & 8 & 30 & 58 & 100 \\
\hline $\begin{array}{l}\text { your boss to discuss business } \\
\text { and technical matters? }\end{array}$ & 6 & 2 & 16 & 26 & 50 & 100 \\
\hline $\begin{array}{l}\text { When you discuss general } \\
\text { topics with your colleagues at } \\
\text { work sports, } \\
\text { politics... etc.)? }\end{array}$ & & & & & & \\
\hline
\end{tabular}

Concerning the language used in meeting new people, Table 5 shows that $46 \%$ of the participants prefer using Arabic when they meet new people while 50\% use both languages and only $4 \%$ prefer using the Turkmen language. However, and as pointed in the same table, the majority of the participants $88 \%$ use Arabic with government officials and only $12 \%$ use both languages. Furthermore, in shopping or going to local businesses, $86 \%$ use Arabic while $10 \%$ use both languages and just $4 \%$ use the Turkmen language. 
Table 5. Language use when meeting new people, with government officials and in shopping

\begin{tabular}{|c|c|c|c|c|c|c|}
\hline Questions & $\begin{array}{c}\text { Only } \\
\text { Turkmen } \\
\%\end{array}$ & $\begin{array}{c}\text { Mostly } \\
\text { Turkmen } \\
\%\end{array}$ & $\begin{array}{c}\text { Turkmen } \\
\& \\
\text { Arabic } \\
\%\end{array}$ & $\begin{array}{c}\text { Mostly } \\
\text { Arabic } \\
\%\end{array}$ & $\begin{array}{c}\text { Only } \\
\text { Arabic } \\
\%\end{array}$ & Total \% \\
\hline $\begin{array}{c}\text { 5. What language do you use } \\
\text { when you meet new people? }\end{array}$ & 2 & 2 & 50 & 16 & 30 & 100 \\
\hline $\begin{array}{c}\text { 6. What language do you use } \\
\text { with Government Officials? }\end{array}$ & - & - & 12 & 34 & 54 & 100 \\
\hline $\begin{array}{c}\text { 7. What language do you use } \\
\text { when you go shopping /go } \\
\text { to local businesses? }\end{array}$ & 2 & 2 & 10 & 34 & 52 & 100 \\
\hline
\end{tabular}

Table 6 below shows that $84 \%$ of the participants use Arabic when they pray; $10 \%$ use both languages and $6 \%$ often use the Turkmen language. When they speak with their fellow worshippers, the majority of them (90\%) prefer using Arabic and $8 \%$ use both languages whereas $2 \%$ use only the Turkmen languages.

Table 6. Language use in the place of worship (Mosque)

\begin{tabular}{|l|c|c|c|c|c|c|}
\hline \multicolumn{1}{|c|}{ Questions } & $\begin{array}{c}\text { Only } \\
\text { Turkmen \% }\end{array}$ & $\begin{array}{c}\text { Mostly } \\
\text { Turkmen \% }\end{array}$ & $\begin{array}{c}\text { Turkmen } \\
\text { Arabic \% }\end{array}$ & $\begin{array}{c}\text { Mostly } \\
\text { Arabic \% }\end{array}$ & $\begin{array}{c}\text { Only } \\
\text { Arabic \% }\end{array}$ & Total \% \\
\hline $\begin{array}{l}\text { 8. What language } \\
\text { do you use in the } \\
\text { places of worship } \\
\text { (mosque). }\end{array}$ & - & 6 & 10 & 32 & 52 & 100 \\
\hline When you pray? & 2 & - & 8 & 34 & 56 & 100 \\
\hline $\begin{array}{l}\text { When you speak } \\
\text { with your fellow } \\
\text { worshippers? }\end{array}$ & 2 & & & & & \\
\hline
\end{tabular}

Similarly, Table 7 below presents results related to the language used when they listen to radio programs. The results indicate that $18 \%$ of the participants prefer Arabic when they listen to radio programs while $60 \%$ prefer both languages and $22 \%$ prefer the Turkmen language. Moreover, $50 \%$ of them choose watching T.V in both languages while $38 \%$ prefer the Turkmen language. When they read newspapers, $24 \%$ of the participants favor Arabic; $54 \%$ favor both languages and $22 \%$ favor the Turkmen language as indicated in the same Table. 
Table 7. Language and media

\begin{tabular}{|l|c|c|c|c|c|c|}
\hline Questions & $\begin{array}{c}\text { Only } \\
\text { Turkmen } \\
\%\end{array}$ & $\begin{array}{c}\text { Mostly } \\
\text { Turkmen } \\
\%\end{array}$ & $\begin{array}{c}\text { Turkmen } \\
\& \\
\text { Arabic } \\
\%\end{array}$ & $\begin{array}{c}\text { Mostly } \\
\text { Arabic } \\
\%\end{array}$ & $\begin{array}{c}\text { Only } \\
\text { Arabic \% }\end{array}$ & Total \% \\
\hline $\begin{array}{l}\text { What language do you } \\
\text { choose when you listen to } \\
\text { radio programs? }\end{array}$ & 2 & 20 & 60 & 14 & 4 & 100 \\
\hline $\begin{array}{l}\text { What is your favorite } \\
\text { language for T.V } \\
\text { entertainment? }\end{array}$ & 10 & 28 & 50 & 8 & 4 & 100 \\
\hline $\begin{array}{l}\text { What language do you use } \\
\text { when you read newspapers? }\end{array}$ & 2 & 20 & 54 & 16 & 8 & 100 \\
\hline
\end{tabular}

Table 8. Language use and emotional self-expressions

\begin{tabular}{|l|c|c|c|c|c|c|}
\hline \multicolumn{1}{|c|}{ Questions } & $\begin{array}{c}\text { Only } \\
\text { Turkmen } \\
\%\end{array}$ & $\begin{array}{c}\text { Mostly } \\
\text { Turkmen } \\
\%\end{array}$ & $\begin{array}{c}\text { Turkmen } \\
\& \text { Arabic } \\
\%\end{array}$ & $\begin{array}{c}\text { Mostly } \\
\text { Arabic } \\
\%\end{array}$ & $\begin{array}{c}\text { Only } \\
\text { Arabic } \\
\%\end{array}$ & $\begin{array}{c}\text { Total } \\
\%\end{array}$ \\
\hline Which language do you prefer & & & & & & \\
\hline $\begin{array}{l}\text { to express your happiness? } \\
\text { when you are extremely angry, } \\
\text { anxious and confused? }\end{array}$ & 40 & 20 & 34 & 2 & 4 & 100 \\
\hline $\begin{array}{l}\text { when you feel very } \\
\text { embarrassed? }\end{array}$ & 36 & 24 & 32 & 6 & 2 & 100 \\
\hline in your dreams? & 44 & 18 & 32 & 2 & 4 & 100 \\
\hline
\end{tabular}

Table 8 shows the results of the language used by the participants when they express their emotions and unconscious feelings. Results indicate that $50 \%$ of the participants use the Turkmen language to express their happiness whereas $40 \%$ use both languages and only $10 \%$ use Arabic .It is reported also that $60 \%$ use the Turkmen language when they are extremely angry, anxious and confused; 32\% use both languages and $8 \%$ use Arabic. Furthermore, results indicate that while $62 \%$ of the participants use the Turkmen language in their dreams, $32 \%$ use both languages and just $6 \%$ use Arabic.

Results reported in the previous Tables prove that the majority of the Turkmen in Baghdad use the Turkmen language at home among family members. Moreover, they use their ethnic language in the emotional self-expressions such as their happiness, anger, confusion and in 
dreaming.

On the other hand, the results show that the majority of the Turkmen in Baghdad use Arabic with their friends in the neighborhood; when they talk to their teachers and their friends at school and university; when they meet new people, with government officials, in shopping or, at work and places of worship (mosque).Furthermore, they use both their ethnic language and Arabic in the media domain especially when listening to radio stations and watching television programs.

The second question deals with the participants' attitudes and feelings towards both the ethnic language of the Turkmen and Arabic. The participants are asked to respond to twenty-three statements about their attitudes towards their ethnic language and Arabic. Each statement is given five options to answer: Strongly disagree, Disagree, Undecided, Agree, Strongly agree.

Table 9 below shows the attitudes of the participants towards their ethnic language (the Turkmen language). Results indicate that the majority of the participants, (98\%), like the Turkmen language and are proud of it. Furthermore, the results indicate that the same ratio is given when the participants are asked whether they can express themselves best in this language while $2 \%$ disagree. Also $92 \%$ agree that they feel at home when they talk in their ethnic language; $6 \%$ are undecided and only $2 \%$ disagree.

When the participants were asked whether knowledge in this language is necessary to maintain the unity of the ethnic group, the majority of them, (96\%), agree; $4 \%$ are undecided and $2 \%$ disagree. Moreover, the majority of the participants, $(96 \%)$, consider the Turkmen language a symbol of their identity and only $2 \%$ are undecided while $2 \%$ disagree. Also the results show that the majority of the participants, $(88 \%)$, regard their ethnic language a symbol of prestige and social status, only $10 \%$ of them are undecided and $2 \%$ disagree.

Whether the Turkmen language is useful and help them at work, $60 \%$ of the participants believe that the Turkmen language does not help them while $20 \%$ are undecided and the same ratio, $(20 \%)$, disagree. Furthermore, $58 \%$ of the participants believe that their ethnic language does not help them in higher education because Arabic is the official language in Iraq and it is the language used in all domains; $20 \%$ are undecided and $22 \%$ disagree. $36 \%$ of the participants believe that because the Turkmen language has many dialects, it makes communication more difficult; $56 \%$ disagree and $8 \%$ undecided.

Moreover, results in Table 9 indicate that the overwhelming majority of the participants, (96\%), regard the Turkmen language as the language of their ancestors and childhood and only $4 \%$ disagree. Also $96 \%$ believe that their ethnic language is associated with the Turkmen's heritage and history and only $4 \%$ disagree. While $80 \%$ of the participants believe that their ethnic language is not dying in their home, while $16 \%$ agree and only $4 \%$ undecided. Finally, 94\% as pointed out in Table 10, regard it important for their children to speak the Turkmen language fluently and only $6 \%$ disagree. 
Table 9. Attitudes towards the Turkmen language

\begin{tabular}{|c|c|c|c|c|c|c|}
\hline Items & $\begin{array}{l}\text { Strongly } \\
\text { Disagree } \\
\%\end{array}$ & $\begin{array}{l}\text { Disagree } \\
\%\end{array}$ & $\begin{array}{l}\text { Undecided } \\
\%\end{array}$ & $\begin{array}{l}\text { Agree } \\
\%\end{array}$ & $\begin{array}{l}\text { Strongly } \\
\text { Agree } \\
\%\end{array}$ & $\begin{array}{c}\text { Total } \\
\%\end{array}$ \\
\hline $\begin{array}{l}\text { I like this language and I am } \\
\text { proud of it. }\end{array}$ & 2 & - & - & 40 & 58 & 100 \\
\hline $\begin{array}{l}\text { I can express myself best in } \\
\text { this language. }\end{array}$ & 2 & - & - & 44 & 54 & 100 \\
\hline $\begin{array}{l}\text { I feel at home when I talk in } \\
\text { this language. }\end{array}$ & 2 & - & 6 & 42 & 50 & 100 \\
\hline $\begin{array}{l}\text { Knowledge of this language } \\
\text { is necessary to maintain the } \\
\text { unity of the ethnic group. }\end{array}$ & 2 & - & 4 & 40 & 54 & 100 \\
\hline $\begin{array}{l}\text { This language is a symbol of } \\
\text { my individual identity. }\end{array}$ & 2 & - & 2 & 28 & 68 & 100 \\
\hline $\begin{array}{l}\text { Knowledge of this language } \\
\text { is a symbol of prestige and } \\
\text { social status. }\end{array}$ & 2 & - & 10 & 32 & 56 & 100 \\
\hline $\begin{array}{l}\text { The Turkmen language does } \\
\text { not help me in the work. }\end{array}$ & 10 & 10 & 20 & 40 & 20 & 100 \\
\hline $\begin{array}{l}\text { The Turkmen language does } \\
\text { not help me in higher } \\
\text { education. }\end{array}$ & 8 & 14 & 20 & 38 & 20 & 100 \\
\hline $\begin{array}{l}\text { The Turkmen language has } \\
\text { many dialects that make the } \\
\text { communication more } \\
\text { difficult. }\end{array}$ & 10 & 46 & 8 & 32 & 4 & 100 \\
\hline $\begin{array}{l}\text { It is the language of my } \\
\text { ancestors. }\end{array}$ & 2 & 2 & - & 40 & 56 & 100 \\
\hline $\begin{array}{l}\text { It is the language of my } \\
\text { childhood. }\end{array}$ & 2 & 2 & - & 40 & 56 & 100 \\
\hline $\begin{array}{l}\text { This language is associated } \\
\text { with the Turkmen's heritage } \\
\text { and history. }\end{array}$ & 2 & 2 & - & 36 & 60 & 100 \\
\hline $\begin{array}{l}\text { This language is dying in my } \\
\text { home. }\end{array}$ & 32 & 48 & 4 & 12 & 4 & 100 \\
\hline $\begin{array}{ll}\text { It is important that my } \\
\text { children speak Turkmen } \\
\text { language fluently. }\end{array}$ & 2 & 4 & - & 44 & 50 & 100 \\
\hline
\end{tabular}

Concerning the attitudes and feelings of the participants towards Arabic, Table 10 above 
shows their opinion towards this language which is the official language of the country and used in different domains.

Table 10. Attitudes towards Arabic

\begin{tabular}{|l|c|c|c|c|c|c|}
\hline \multicolumn{1}{|c|}{ Items } & $\begin{array}{c}\text { Strongly } \\
\text { Disagree } \\
\%\end{array}$ & $\begin{array}{c}\text { Disagree } \\
\%\end{array}$ & $\begin{array}{c}\text { Undecided } \\
\%\end{array}$ & $\begin{array}{c}\text { Agree } \\
\%\end{array}$ & $\begin{array}{c}\text { Strongly } \\
\text { Agree } \\
\%\end{array}$ & $\begin{array}{c}\text { Total } \\
\%\end{array}$ \\
\hline $\begin{array}{l}\text { I prefer to use Arabic for social } \\
\text { mobility. }\end{array}$ & 4 & 16 & 16 & 48 & 16 & 100 \\
\hline $\begin{array}{l}\text { It is important for promoting } \\
\text { religious unity in the } \\
\text { community. for }\end{array}$ & 2 & 8 & 10 & 54 & 26 & 100 \\
\hline $\begin{array}{l}\text { It is necessary } \\
\text { communication with other } \\
\text { constituents of Iraqi society. }\end{array}$ & - & 2 & 10 & 68 & 20 & 100 \\
\hline It is necessary for getting jobs. & 2 & 2 & 12 & 66 & 18 & 100 \\
\hline $\begin{array}{l}\text { It is necessary for conducting } \\
\text { business. }\end{array}$ & - & 6 & 12 & 66 & 16 & 100 \\
\hline $\begin{array}{l}\text { It is important that I speak } \\
\text { Arabic in all domains. }\end{array}$ & - & 14 & 12 & 48 & 26 & 100 \\
\hline $\begin{array}{l}\text { Arabic is the official language } \\
\text { so, it must be learned }\end{array}$ & - & 4 & 4 & 62 & 30 & 100 \\
\hline $\begin{array}{l}\text { Arabic is more important than } \\
\text { Turkmen language. }\end{array}$ & 8 & 52 & 14 & 20 & 6 & 100 \\
\hline $\begin{array}{l}\text { It is better to learn Arabic in } \\
\text { order to spread social and } \\
\text { cultural values of the Iraqi } \\
\text { society. }\end{array}$ & 2 & 8 & 14 & 48 & 28 & 100 \\
\hline
\end{tabular}

When the participants were asked whether they prefer to use Arabic for social mobility, the results indicate that $64 \%$ agree with this statement, only $16 \%$ undecided while $20 \%$ disagree. With regard to the importance of Arabic in promoting religious unity in the community, $80 \%$ of the participants agree while $10 \%$ are undecided and the same percentage, $10 \%$, disagree. When the participants were asked about the importance of Arabic for communication with other constituents of Iraqi society, the majority (88\%) agree, $10 \%$ undecided and only 2\% disagree. Moreover, while the results indicate that $84 \%$ of the participants believe that Arabic is necessary for getting jobs $12 \%$ undecided and $4 \%$ disagree. Similarly, $82 \%$ of the participants report that Arabic is necessary for conducting business, $12 \%$ undecided and $6 \%$ disagree with this statement.

Concerning the importance of speaking Arabic in all domains, $74 \%$ of the participants agree, $12 \%$ undecided and $14 \%$ of them disagree. The majority of the participants, $92 \%$, consider Arabic the official language and therefore it must be learned. Furthermore, $60 \%$ of the participants do not agree that Arabic is more important than Turkmen, 26\% agree and only 
$14 \%$ are undecided. Finally, the results show that $76 \%$ of the participants consider Arabic better to learn in order to spread social and cultural values of the Iraqi society while $14 \%$ undecided and only $10 \%$ disagree.

\section{Discussion and Conclusions}

\subsection{Discussion}

Results related to the domains of language use among the Turkmen of Baghdad show that although the Turkmen people use the majority language (Arabic) in different domains when they talk with different people about various subjects, they use their ethnic language (Turkmen language) at home with family members.

Table 1 indicates that most of Turkmen people use their ethnic language (Turkmen language) when they talk with family members and relatives (father, mother, children, brothers and sisters) over the phone, family meetings and in meeting relatives face-to-face while few of them use both languages (Arabic and Turkmen). Moreover, all of them use only the Turkmen language with the grandparents. The use of the Turkmen language at home and among family members proves that they are proud in preserving it. They speak with their children frequently in the Turkmen language and teach them to maintain it. This result agrees with Clyne (2001) who emphasizes the important role that the grandparents play in maintaining the mother tongue.

Results reported in Table 2 and Table 3 concerning the language used in the neighborhood and in schools and universities demonstrate that Arabic is used by the Turkmen more than the ethnic language when they talk with their friends and people in the neighborhood and when they talk with teachers and friends. They use Arabic due to mixing with other people from other minorities who do not know the Turkmen language. These results match those of Dweik and Qawar (2015) who have reported that the Arabs of Quebec use the mainstream language in educational institutions.

Again, results shown in Table 4 indicate that the vast majority of the participants use Arabic at work when talking with fellow employees, discussing business and technical matters with the boss or general topics. Similarly, the results in Table 4 show Arabic as the predominant language used by the participants when talking with government officials as well as when shopping or going to local businesses, with their colleagues at work when discussing topics such as weather, sports and politics.

These results agree with Fishman (1989) who believes that in some cases partial language shift is possible. The ethnic language is replaced only in certain areas of interaction "and a new pattern of inter-generational continuity is then stabilized." (p.178) Moreover, half of the participants use both Turkmen language and Arabic when meeting new people as shown in Table 5.

The vast majority of the participants as reported in Table 6 use Arabic in the places of worship (Mosque).They predominantly use Arabic in praying and in talking with worshipers. This result supports the findings of Dweik and Al-Obaidi (2014) who have maintained that 
the Chaldo Assyrians of Baghdad use their ethnic language the place of worship.

Furthermore, the study, as reported in Table 7, indicates that most of the participants use both Turkmen and Arabic when listening to radio programs, watching T.V. programs and even when reading newspapers. This means that they are proud of their ethnic language. The presence of mass media in the Turkmen language is considered a key factor in maintaining it.

Results reported in Table 8 indicate that more than half of the participants use the Turkmen language to express their emotions and unconscious feelings especially when expressing their happiness and when they are extremely angry, anxious or confused about their dreams. This result corresponds with Dweik and Nofal (2015) who have found that the Indian ethnic languages are vital in the media and emotional feelings domains.

Regarding language attitudes towards the Turkmen and Arabic languages, the results reported in Tables 9 and 10 show the participants' positive attitudes towards both languages. Table 9 indicates the attitudes towards the Turkmen language among the Turkmen of Baghdad. The vast majority of them like their ethnic language and they are so proud of it . They can express themselves well in this language. When they talk in their ethnic language, most of them feel at home and enjoy using it. They believe that in order to preserve their ethnic language, they must learn it. It is the symbol of their ethnic and individual identity. Moreover, a great number of them assert that their ethnic language is not useful in the work domain and in higher education because it is different from Arabic which is the official language and the language of the majority.

More than half of the participants assert that although the Turkmen language has many dialects, they are able to communicate well in it. The majority of them believe that it is the language of their ancestors and their childhood. In addition to this, the Turkmen language is associated with the Turkmen's heritage and history.

Most of the Turkmen maintain their ethnic language especially in their homes among their family members. This language is alive in the home. They encourage their children to use the Turkmen language fluently to communicate with others.

These results agree with Khadidja (2013) who mentioned that the Kabyle speakers of Oran showed positive attitudes towards their native language. These positive attitudes proved that they helped them to maintain the Kabyle variety in the speech community of Oran despite the fact that the predominant language is Algerian Arabic. The positive attitudes also reflect their loyalty to the Kabyle language and culture.

Similarly, results reported in Table 10 show that the Turkmen people have a positive attitude towards Arabic .The majority of them use Arabic for social mobility; for enhancing the unity of the Islamic religion; for communicating with other constituents and minorities and also for spreading social and cultural values in Iraqi society.

Most of the participants assume that Arabic is an important language in order to get jobs or conduct business. The vast majority believe that Arabic is the mainstream one in Iraq. Therefore, they must learn and use it in all domains. More than half of the participants do not 
consider Arabic as more important than Turkmen. This indicates their strong loyalty to their language. This result supports those of Dweik and Nofal (2015) in that the Indo-Yemenis hold positive attitudes towards the mainstream language, Arabic.

\subsection{Conclusions}

The analysis of the overall results of the questionnaire confirms that the Turkmen ethnic language has been in use for many centuries despite as the presence of an ancient language such as Arabic which is the official language in Iraq. Conclusions could be drawn in answer to the research questions as follows:

1. The Turkmen use their ethnic language in various domains, especially at home among their family members and relatives. Moreover, they use the Arabic language side by side with their native language.

2. The Turkmen people have positive attitudes towards their mother tongue. They see it as a symbol of their national identity and they are very proud of this language. It is the language of their ancestors and childhood. This language is closely associated with their heritage and history. With regard to Arabic, the Turkmen also have positive attitudes towards it. They use it predominantly in all domains because it is the official language of the country as well as it is the language of the Islamic religion. The Turkmen people mix their ethnic language and Arabic unconsciously. Knowledge of Arabic is vital in schools and universities, to get good jobs and to communicate with the whole society.

\section{References}

Clyne, M. (1982). Multilingual Australia. Melbourne: River Seine.

Dweik, B. and Nofal, M. (2015). Linguistic Choices and Perceptions in Multilingual Spheres: The Case of the Indo-Yemenis. Journal of Social Sciences and Humanities, 1(3), 235-244

Dweik, B., \& Al-Obaidi, T. (2014). Language contact, use and attitudes among the Chaldo-Assyrians of Baghdad, Iraq: A sociolinguistic study. Journal of Advances in Linguistics, 3(3), 219-232.

Dweik, B., \& Qawar, H. (2015). Language choice and language attitudes in a multilingual Arab Canadian community: Quebec-Canada: A sociolinguistic study. British Journal of English Linguistics, 3(1), 1-12.

Fishman, J. A. (1989). Language and ethnicity in minority sociolinguistic perspective. England: Multilingual Matters LTD.

Holmes, J. (1992). An introduction to sociolinguistics. London: Longman.

Jagodic, D. (2011). Between language maintenance and language shift: The Slovenian community in Italy today and tomorrow. Slovene Research Institute, 2(1), 195- 213.

Khadidja, A. (2013). Language maintenance and language shift among Kabyle speakers in Arabic speaking communities: The case of Oran. (Unpublished M.A thesis), University of Oran, Algeria. 


\section{Macrothink}

Park, S. M., \& Sarkar, M. (2007). Parents' attitudes toward heritage language maintenance for their children and their efforts to help their children to maintain the heritage language: A case study of Korean-Canadian immigrants. Language, Culture and Curriculum, 20(3), 223-235.

Somer, F. (1967). The Oguz Turkmen. Ankara: Ankara Press.

Zhang, D., \& Slaughter-Defoe, D. (2009). Language attitudes and heritage language maintenance among Chinese immigrant families in the USA. Language, Culture and Curriculum, 22(2), 77-93.

\section{Copyright Disclaimer}

Copyright for this article is retained by the author(s), with first publication rights granted to the journal.

This is an open-access article distributed under the terms and conditions of the Creative Commons Attribution license (http://creativecommons.org/licenses/by/3.0/). 